\title{
Efficacy of Organic Amendments and a Nematicide for the Management of Root-Knot Nematode (Meloidogyne incognita) of Tomato
}

\author{
Md. Iqbal Faruk \\ Plant Pathology Division, Bangladesh Agricultural Research Institute, Bangladesh \\ Received July 29, 2019; Revised December 25, 2019; Accepted December 30, 2019
}

Copyright $(2020$ by authors, all rights reserved. Authors agree that this article remains permanently open access under the terms of the Creative Commons Attribution License 4.0 International License

\begin{abstract}
A field experiment was conducted in the field of Plant Pathology Division, Bangladesh Agricultural Research Institute to find out the efficacy of organic amendments viz. poultry refuse, rice bran , fresh saw dust, dry saw dust, tea waste and a nematicide Furadan 5G against root-knot disease (Meloidogyne incognita) of tomato during three consecutive years viz. 2012-13, 2013-14 and 2014-15. Soil was treated with different organic amendments 10 days before seedling transplanting and Furadan 5G was applied on the day of seedling transplanting of tomato. The soils of the experimental plots were inoculated with chopped severely galled ( $M$. incognita) roots of tomato at the time of treatment application. In all the years, considerable reduction in root-knot disease and increase in plant growth and fruit yield were achieved with different treatments and Furadan 5G. The most effective treatment was poultry refuse followed by rice bran and Furadan 5G. In $1^{\text {st }}$ year, $2^{\text {nd }}$ year and $3^{\text {rd }}$ year, gall index values were 5.16, 4.94 and 6.27 under control, respectively. The severity was reduced to $59.11-64.53 \%$ in $1^{\text {st }}$ year, $50.60-60.72 \%$ in $2^{\text {nd }}$ year and 48.96-55.34\% in the $3^{\text {rd }}$ year compared to control due to application of the rice bran, Furadan $5 \mathrm{G}$ and poultry refuse. On the other hand, fruit yield under control was $44.82 \mathrm{t} / \mathrm{ha}$ at $1^{\text {st }}$ year $49.73 \mathrm{t} /$ ha in $2^{\text {nd }}$ year and $36.95 \mathrm{t} / \mathrm{ha}$ at $3^{\text {rd }}$ year. The highly effective three treatments increased fruit yield to $11.02-29.90 \%$ in $1^{\text {st }}$ year, $17.17-30.56 \%$ in $2^{\text {nd }}$ year and $23.39-35.02 \%$ in the $3^{\text {rd }}$ year compared to control. The fruit yield of tomato was directly and linearly correlated with gall indices in tomato gall. Based on the findings of present the study poultry refuse and rice bran noted as an effective treatment to manage root-knot disease of tomato.
\end{abstract}

Keywords Poultry Refuse, Rice Bran, Saw Dust, Tea Waste, Furadan, Meloidogyne incognita, Tomato

\section{Introduction}

Tomato (Lycopersicon esculentum L.) is one of the most popular and nutritious vegetable crops in Bangladesh which belongs to the family Solanaceae. It ranks next to potato and sweet potato in respect of vegetable production in the world $(1,2)$ and tops the list of conned vegetables (3). The average yield of tomato in Bangladesh is $14.05 \mathrm{t} / \mathrm{ha}$ (4) which is quite low as compared to that of other tomato producing countries in the World (5). The low yield was mainly attributed to the susceptible nature of the crop to insect pests and diseases among which plant-parasitic nematodes are one of the most prevalent (6). Plant-parasitic nematodes have been implicated as a major constraint to tomato production (7). In general, the most widespread nematode species are the root-knot nematodes (Meloidogyne spp.). The root-knot nematodes are an economically important group of plant-parasitic nematodes (8). The common root-knot nematodes identified as parasites of tomatoes in the tropics are: $M$. incognita (Kofoid and White), M. javanica (Treub), and M. arenaria (Neal) of which $M$. incognita is the most important (9). Yield loss of about $20.6 \%$ in tomatoes has been attributed to Meloidogyne species $(10,11)$. It causes about $40 \%$ yield loss of tomato in Bangladesh and about $46.2 \%$ yield reduction in India $(12,13)$. A number of approaches aimed to control root-knot nematodes through application of nematicides (14), organic soil amendments $(15,16,17,18)$, cultural management, physical methods like soil solarization and biological measures like Trichoderma spp, Pacecilomyces lilacinus, Pasturia penetrans and Pseudomonas aeruginosa (19, 20, 21). Tomato cultivar resistant to root-knot nematode is not available in Bangladesh. For many years chemical nematicides have been used to control plant parasitic nematodes effectively. Although these are effective and fast acting, they are degrading to the environment, other beneficial soil micro 
flora and human health (22). Therefore, alternate management options against the nematodes are to be sought. Organic amendments derived from livestock manure, sewage wastes and different composts have been reported to have an effect on plant parasitic nematodes and free living micro flora (23, 24 25, 26). Organic amendments have been identified to enhance soil fertility and soil microbial populations (27), as well as suppress plant-parasitic nematodes (28). Therefore, the present study was undertaken to identify organic amendments with potentials to increase yield of tomato and to reduce root-knot nematode of tomato.

\section{Materials and Methods}

A field experiment was conducted to test efficacy of available organic amendments namely saw dust, rice bran , poultry refuses containing bedding materials and tea waste and a nematicide Furadan 5G (Carbofuran) to control root-knot nematode of tomato. The experiment was conducted in three consecutive years viz. 2012-13, 2013-14 and 2014-15 in the field of Plant Pathology Division BARI, Joydebpur, Gazipur. A total of 7 treatments including a control viz. i) Furadan (F) 5G @ 40 kg/ha, ii) Fresh saw dust @2.5 t/ha, iii) Dry saw dust @2.0 t/ha, iv) Rice bran @ 2.0 t/ha, v) Poultry refuse @ 5 t/ha, vi) Tea waste@ 2 t/ha and vii) Untreated control. The experiment was laid out in a randomized complete block design with 3 replications. The unit plot size $3 \mathrm{~m} \times 2.5 \mathrm{~m}$ keeping $1 \mathrm{~m}$ distance from plot to plot. Standard cultivation procedures recommended by BARI were followed to grow tomato with little modification. The experimental land was prepared with proper tillage and fertilizers were added during final land preparation. Requisite quantity of all organic amendments were incorporated with the soil 10 days before transplanting of tomato seedlings and allowed to decompose properly. Furadan 5G was applied in the field just before transplanting of seedlings. To ensure inocula of the nematode, chopped severely galled tomato roots infected with $M$. incognita were mixed with soil around the tomato seedlings @ 2 g/plant. Twenty five days old and apparently healthy tomato seedlings of variety BARI Tomato-2 (Ratan) were transplanted in the experimental plots maintaining row to row and plant to plant distance of $60 \mathrm{~cm}$ and $50 \mathrm{~cm}$, respectively. Ten additional seedlings per plot were also transplanted in between two rows. During crop season necessary weeding, irrigation and other intercultural operations were done as per recommendation of the crop (29).

\subsection{Data Collection}

Data on shoot length, shoot weight, root length, root weight, gall index and yield were recorded. The root-knot disease severity was recorded two time one at 65 days after transplanting and another one after final harvest of tomato. The additional ten plants per plot were carefully uprooted after 65 days of transplanting and the root systems were cleaned with running tap water. Data on length and weight of shoot and root were recorded. The severity of root gall was recorded in terms of gall index based on a 0-10 scale (30). Data on fruit yield were recorded from five randomly selected plants per plot. The fruit yield was expressed in t/ha.

\section{Results}

Shoot growth: Average shoot length of tomato under control was $45.67 \mathrm{~cm} /$ plant in first year $50.28 \mathrm{~cm} /$ plant in second year and $45.00 \mathrm{~cm} /$ plant in the third year (Table 1 ). Treatment of soil with different organic amendments and Furadan 5G increased the parameter to 53.06-63.06 $\mathrm{cm} /$ plant in the first year, $59.22-75.55 \mathrm{~cm} /$ plant in the second year and $56.20-71.27 \mathrm{~cm} /$ plant in the third year (Table 1). In the first year, the highest shoot length was obtained with poultry refuse followed by rice bran, tea waste, Furadan 5G and fresh saw dust. The lowest shoot length was recorded from control. More or less similar results also observed in the second year where the maximum shoot length was recorded from plots treated with poultry refuse by $75.55 \mathrm{~cm} /$ plant. In the third year maximum shoot length was recorded from the poultry refuse and rice bran treated plots followed by fresh saw dust and Furadan 5G. The least effective treatments to increase shoot length was dry saw dust followed by tea waste (Table 1).

In the first year, the shoot weight of tomato was only $218.3 \mathrm{~g} /$ plant under control (Table 1). It increased to 231.7.0-347.2 g/plant due to treatments with organic amendments and Furadan 5G. The highest shoot weight was achieved with poultry refuse followed by rice bran, Furadan 5G and fresh saw dust. The least effective treatment to increase shoot weight was dry saw dust, which was followed by tea waste. In the second year, the shoot weight of tomato was $268.3 \mathrm{~g} /$ plant in control. Application of poultry refuse gave the highest shoot weight of 466.8 g/plant followed by rice bran , Furadan $5 \mathrm{G}$ and fresh saw dust where the shoot weight was $393.3 \mathrm{~g} / \mathrm{plant}, 368.3$ g/plant and $344.4 \mathrm{~g} /$ plant, respectively (Table 1 ). In the third year application different treatments gave higher shoot weight over control within the range of 154.70-236.50 g/plant. Two treatments with poultry refuse and rice bran yielded higher shoot weight. The least effective treatment to increase shoot weight was dry saw dust followed by tea waste (Table 1). 
Table 1. Effect of soil treatment with organic amendments and a nematicide on shoot growth of tomato in three consecutive years

\begin{tabular}{|c|c|c|c|c|c|c|}
\hline \multirow{2}{*}{ Treatments } & \multicolumn{3}{|c|}{ Shoot length $\left(\mathrm{cmplant}^{-1}\right)$} & \multicolumn{3}{c|}{ Shoot weight (gplant $\left.{ }^{-1}\right)$} \\
\cline { 2 - 7 } & $2012-13$ & $2013-14$ & $2014-15$ & $2012-13$ & $2013-14$ & $2014-15$ \\
\hline Furadan 5G & $55.00 \mathrm{~b}$ & $64.11 \mathrm{~b}$ & $58.73 \mathrm{~b}$ & $272.8 \mathrm{bc}$ & $368.3 \mathrm{bc}$ & $154.70 \mathrm{bc}$ \\
\hline Fresh saw dust & $54.46 \mathrm{~b}$ & $62.33 \mathrm{~b}$ & $57.73 \mathrm{~b}$ & $263.9 \mathrm{bc}$ & $344.4 \mathrm{bc}$ & $165.90 \mathrm{bc}$ \\
\hline Dry saw dust & $53.06 \mathrm{~b}$ & $59.22 \mathrm{~b}$ & $56.20 \mathrm{~b}$ & $231.7 \mathrm{c}$ & $331.1 \mathrm{c}$ & $171.20 \mathrm{bc}$ \\
\hline Rice bran & $56.17 \mathrm{~b}$ & $65.00 \mathrm{~b}$ & $66.06 \mathrm{a}$ & $296.7 \mathrm{ab}$ & $393.3 \mathrm{~b}$ & $198.00 \mathrm{ab}$ \\
\hline Poultry refuse with waste materials & $63.06 \mathrm{a}$ & $75.55 \mathrm{a}$ & $71.27 \mathrm{a}$ & $347.2 \mathrm{a}$ & $466.8 \mathrm{a}$ & $236.50 \mathrm{a}$ \\
\hline Tea waste & $55.44 \mathrm{~b}$ & $59.28 \mathrm{~b}$ & $58.53 \mathrm{~b}$ & $264.4 \mathrm{bc}$ & $339.1 \mathrm{bc}$ & $170.60 \mathrm{bc}$ \\
\hline Control & $45.67 \mathrm{c}$ & $50.28 \mathrm{c}$ & $45.00 \mathrm{c}$ & $218.3 \mathrm{c}$ & $268.3 \mathrm{~d}$ & $133.50 \mathrm{c}$ \\
\hline LSD (P=0.05) & 4.603 & 7.087 & 5.241 & 56.08 & 51.09 & 40.31 \\
\hline
\end{tabular}

Values within the same column with a common letter do not differ significantly $(\mathrm{P}=0.05)$

Table 2. Efficacy of soil treatment with organic amendments and a nematicide on root growth of tomato in three consecutive years

\begin{tabular}{|c|c|c|c|c|c|c|}
\hline \multirow{2}{*}{ Treatments } & \multicolumn{3}{|c|}{ Root length $\left(\mathrm{cmplant}^{-1}\right.$ ) } & \multicolumn{3}{c|}{ Root weight (gplant $^{-1}$ ) } \\
\cline { 2 - 7 } & $2012-13$ & $2013-14$ & $2014-15$ & $2012-13$ & $2013-14$ & $2014-15$ \\
\hline Furadan 5G & 25.89 & $28.33 \mathrm{bc}$ & $24.13 \mathrm{c}$ & $16.67 \mathrm{~b}$ & $18.78 \mathrm{ab}$ & $13.60 \mathrm{ab}$ \\
\hline Fresh saw dust & 22.67 & $28.17 \mathrm{bc}$ & $23.93 \mathrm{c}$ & $15.11 \mathrm{bc}$ & $16.67 \mathrm{~b}$ & $12.00 \mathrm{abc}$ \\
\hline Dry saw dust & 22.67 & $26.66 \mathrm{c}$ & $21.73 \mathrm{c}$ & $12.50 \mathrm{c}$ & $17.61 \mathrm{~b}$ & $11.20 \mathrm{bc}$ \\
\hline Rice bran & 24.17 & $31.28 \mathrm{ab}$ & $29.00 \mathrm{~b}$ & $16.50 \mathrm{~b}$ & $19.11 \mathrm{ab}$ & $14.53 \mathrm{ab}$ \\
\hline Poultry refuse with waste materials & 25.94 & $32.44 \mathrm{a}$ & $32.20 \mathrm{a}$ & $22.22 \mathrm{a}$ & $24.17 \mathrm{a}$ & $15.80 \mathrm{a}$ \\
\hline Tea waste & 23.00 & $27.72 \mathrm{bc}$ & $23.60 \mathrm{c}$ & $14.04 \mathrm{bc}$ & $17.78 \mathrm{~b}$ & $12.40 \mathrm{abc}$ \\
\hline Control & 21.00 & $21.89 \mathrm{~d}$ & $16.93 \mathrm{~d}$ & $12.22 \mathrm{c}$ & $16.39 \mathrm{~b}$ & $8.43 \mathrm{C}$ \\
\hline LSD (P=0.05) & NS & 3.471 & 3.101 & 3.63 & 5.24 & 4.02 \\
\hline
\end{tabular}

Values within the same column with a common letter do not differ significantly $(\mathrm{P}=0.05)$

Root growth: Amendment of soil with poultry refuse, rice bran and fresh saw dust and application of Furadan 5G showed positive effects on root growth of tomato as compared to control (Table 2). In the first year, significant difference was not observed among the treatment including control. In the second year, root length under control was only $21.89 \mathrm{~cm} /$ plant. It was increased to 26.66-32.44 $\mathrm{cm} /$ plant due to application of poultry refuse, rice bran, Furadan 5G, saw dust and tea waste. In the third year, the minimum root length of $16.93 \mathrm{~cm} /$ plant was recorded under control. The highest root length of $32.20 \mathrm{~cm} /$ plant was achieved with poultry refuse followed by the treatments with rice bran giving $29.00 \mathrm{~cm} /$ plant root length (Table 2). Other five treatments also increased root length over control within the range of $21.73-24.13 \mathrm{~cm} /$ plant.

In the first year, root weight was $12.20 \mathrm{~g} /$ plant under control. It was increased 14.04 to $22.22 \mathrm{~g}$ /plant due to application of poultry refuse, rice bran , fresh saw dust and Furadan 5G (Table 2). In the second year, root weight increased to some extent over control showing 16.39 g/plant under control and 18.78-24.17 g/plant in plots treated with poultry refuse, rice bran and Furadan 5G (Table 2). The least effective treatment was dry saw dust followed by tea waste and fresh saw dust. In the third year, the minimum root weight was $8.43 \mathrm{~g} / \mathrm{plant}$ in control. The maximum root weight was $15.80 \mathrm{~g} /$ plant in plot treated with poultry refuse followed by rice bran, Furadan $5 \mathrm{G}$, tea waste and fresh saw dust.

Severity of root gall: In all the years, the severity of root gall of tomato was drastically reduced over control due to treatment of soil with organic amendments viz. poultry refuse, rice bran , saw dust and application of Furadan 5G 
(Table 3). In the first year, the maximum average gall index value of 5.16 was recorded in the control plot. It was reduced to 1.83 to 3.45 due to treatments with organic amendments and the Furadan 5G. The lowest severity of root-knot disease of tomato was recorded from the treatment with poultry refuse which was followed by Furadan 5G, rice bran , fresh saw dust and tea waste but all the treatments are statistically identical except dry saw dust. Application of poultry refuse gave $64.53 \%$ reduction of root knot disease severity compared to control followed by Furadan 5G, rice bran, fresh saw dust and tea waste where the reduction disease severity was $60.08 \%, 59.11 \%$, $55.81 \%$ and $52.71 \%$, respectively compared to control (Table 3).

In the second year, the highest gall index value of 4.94 was found in control plot and the values were reduced to 1.94 to 3.11 due to application of different treatments (Table 3). The reduction in disease severity was significant compared to control. The maximum reduction $60.72 \%$ over control was obtained with poultry refuse followed by Furadan 5G, rice bran and fresh saw dust with the reduction of $51.82 \%, 50.60 \%$ and $47.17 \%$ respectively compared to control. The least effective treatment to reduce root galling was dry saw dust followed by tea waste (Table 3). More or less similar trend also observed in the third year where the maximum gall index value of 6.27 was found in the control treatment. Application of poultry refuse gave the maximum $55.34 \%$ reduction of root knot disease severity compared to control followed by Furadan 5G and rice bran with 51.03\% and $58.96 \%$ reduction of root knot disease severity than control.

Crop yield: Organic soil amendments and Furadan 5G gave appreciable increase in fruit number/plant and fruit yield per hectare in all the years (Table 4). However, yield increase was not significant under all treatments compared to control (Table 4).

Under control, fruit number per plant was 23.11 in the $1^{\text {st }}$ year, 23.60 in the $2^{\text {nd }}$ year and 20.53 in the $3^{\text {rd }}$ year (Table 4). Fruit number per plant increased to $23.36-29.11$ in the $1^{\text {st }}$ year $26.27-32.27$ in the $2^{\text {nd }}$ year and 25.07-32.40 in the $3^{\text {rd }}$ year due to different treatments. In the $1^{\text {st }}$ year, only the treatments with poultry refuse increased fruit number significantly over control. In the $2^{\text {nd }}$ year, all treatments with poultry refuse, rice bran and Furadan 5G caused significant increase in fruit number over control. The lowest increase $10.16 \%$ than control was achieved with dry saw dust followed by tea waste and fresh saw dust treatments with increased $10.61 \%$ and $10.84 \%$, respectively compared to control. Poultry refuse gave the highest increased of fruit number with $26.87 \%$ over control, which statistically similar to rice bran (Table 4). In the $3^{\text {rd }}$ year, all the treatments significantly increased fruits number per plant compared to control. The highest fruits number per plant was 32.40 by poultry refuse treatment which is significantly differed from other treatments. Soil treatment with poultry refuse gave $36.64 \%$ higher yield than control which was followed by rice bran , fresh saw dust and Furadan 5G where the fruits number was 25.07\%, $23.96 \%$ and $23.60 \%$, respectively higher than control (Table 4).

In the first year, the lowest fruit yield of $44.82 \mathrm{t} / \mathrm{ha}$ was found under control (Table 4). The yield was increased to 46.53 to 58.22 t/ha due to application of different treatments with poultry refuses, rice bran, Furadan $5 \mathrm{G}$ and saw dust. The maximum yield was obtained with poultry refuse where fruit yield was $29.90 \%$ higher compared to control which followed by Furadan5G with $16.47 \%$ higher yield than control (Table 5). Differences in fruit yield harvested from control plots and plots treated with rice bran , saw dust and tea waste was not significant.

Table 3. Efficacy of soil treatment with organic amendment and nematicide on the severity of root -knot disease (Meloidogyne incognita) of tomato in three consecutive years

\begin{tabular}{|c|c|c|c|c|c|c|}
\hline \multirow{2}{*}{ Treatments } & \multicolumn{3}{|c|}{ Gall Index (0-10 scale) } & \multicolumn{2}{c|}{ Reduction of gall index over control (\%) } \\
\cline { 2 - 7 } & $2012-13$ & $2013-14$ & $2014-15$ & $2012-13$ & $2013-14$ & $2014-15$ \\
\hline Furadan 5G & $2.06 \mathrm{c}$ & $2.38 \mathrm{~cd}$ & $3.07 \mathrm{c}$ & 60.08 & 51.82 & 51.03 \\
\hline Fresh saw dust & $2.44 \mathrm{c}$ & $2.61 \mathrm{c}$ & $3.40 \mathrm{bc}$ & 52.71 & 47.17 & 45.77 \\
\hline Dry saw dust & $3.45 \mathrm{~b}$ & $3.11 \mathrm{ab}$ & $3.80 \mathrm{~b}$ & 33.14 & 37.04 & 39.39 \\
\hline Rice bran & $2.11 \mathrm{c}$ & $2.44 \mathrm{c}$ & $3.20 \mathrm{bc}$ & 59.11 & 50.60 & 48.96 \\
\hline $\begin{array}{c}\text { Poultry refuse with waste } \\
\text { materials }\end{array}$ & $1.83 \mathrm{c}$ & $1.94 \mathrm{~d}$ & $2.80 \mathrm{c}$ & 64.53 & 60.72 & 55.34 \\
\hline Tea waste & $2.28 \mathrm{c}$ & $2.78 \mathrm{bc}$ & $3.40 \mathrm{bc}$ & 55.81 & 43.72 & 45.77 \\
\hline Control & $5.16 \mathrm{a}$ & $4.94 \mathrm{a}$ & $6.27 \mathrm{a}$ & - & & - \\
\hline LSD (P=0.05) & 1.17 & 0.477 & 0.593 & - & & - \\
\hline
\end{tabular}

Values within the same column with a common letter do not differ significantly $(\mathrm{P}=0.05)$ 
Table 4. Efficacy of soil treatment with organic amendment and a nematicide on the fruit number per plant of tomato in soil inoculated with Meloidogyne incognita

\begin{tabular}{|c|c|c|c|c|c|c|}
\hline \multirow{2}{*}{ Treatments } & \multicolumn{3}{|c|}{ Number of Fruits per plant } & \multicolumn{3}{c|}{ Number of fruits increased over control (\%) } \\
\cline { 2 - 7 } & $2012-13$ & $2013-14$ & $2014-15$ & $2012-13$ & $2013-14$ & $2014-15$ \\
\hline Furadan 5G & $24.72 \mathrm{~b}$ & $27.53 \mathrm{bc}$ & $26.87 \mathrm{~b}$ & 6.51 & 14.27 & 23.60 \\
\hline Fresh saw dust & $24.39 \mathrm{~b}$ & $26.40 \mathrm{~cd}$ & $27.00 \mathrm{~b}$ & 5.25 & 10.61 & 23.96 \\
\hline Dry saw dust & $23.66 \mathrm{~b}$ & $26.47 \mathrm{~cd}$ & $25.07 \mathrm{~b}$ & 2.32 & 10.84 & 18.11 \\
\hline Rice bran & $23.89 \mathrm{~b}$ & $30.13 \mathrm{ab}$ & $27.40 \mathrm{~b}$ & 3.26 & 21.67 & 25.07 \\
\hline Poultry refuse with waste materials & $29.11 \mathrm{a}$ & $32.27 \mathrm{a}$ & $32.40 \mathrm{a}$ & 20.61 & 26.87 & 36.64 \\
\hline Tea waste & $23.36 \mathrm{~b}$ & $26.27 \mathrm{~cd}$ & $25.80 \mathrm{~b}$ & 1.07 & 10.16 & 20.43 \\
\hline Control & $23.11 \mathrm{~b}$ & $23.60 \mathrm{~d}$ & $20.53 \mathrm{c}$ & - & - & - \\
\hline LSD (P=0.05) & 2.025 & 3.277 & 4.41 & - & & - \\
\hline
\end{tabular}

Values within the same column with a common letter do not differ significantly $(\mathrm{P}=0.05)$

Table 5. Efficacy of soil treatment with organic amendment and a nematicide on the fruit yield of tomato in soil inoculated with Meloidogyne incognita

\begin{tabular}{|c|c|c|c|c|c|c|}
\hline \multirow{2}{*}{ Treatments } & \multicolumn{3}{|c|}{ Fruits yield (tha ${ }^{-1}$ ) } & \multicolumn{3}{c|}{ Yield increased over control (\%) } \\
\cline { 2 - 8 } & $2012-13$ & $2013-14$ & $2014-15$ & $2012-13$ & $2013-14$ & $2014-15$ \\
\hline Furadan 5G & $52.20 \mathrm{~b}$ & $60.04 \mathrm{~b}$ & $51.50 \mathrm{ab}$ & 16.47 & 17.17 & 28.25 \\
\hline Fresh saw dust & $48.11 \mathrm{bc}$ & $59.07 \mathrm{bc}$ & $47.02 \mathrm{~b}$ & 07.34 & 15.81 & 21.42 \\
\hline Dry saw dust & $47.98 \mathrm{bc}$ & $55.07 \mathrm{bc}$ & $45.35 \mathrm{~b}$ & 07.05 & 09.69 & 18.52 \\
\hline Rice bran & $49.76 \mathrm{bc}$ & $64.40 \mathrm{ab}$ & $48.23 \mathrm{~b}$ & 11.02 & 22.77 & 23.39 \\
\hline Poultry refuse with waste materials & $58.22 \mathrm{a}$ & $71.62 \mathrm{a}$ & $56.86 \mathrm{a}$ & 29.90 & 30.56 & 35.02 \\
\hline Tea waste & $46.53 \mathrm{bc}$ & $54.56 \mathrm{bc}$ & $45.98 \mathrm{~b}$ & 03.81 & 08.85 & 19.64 \\
\hline Control & $44.82 \mathrm{c}$ & $49.73 \mathrm{c}$ & $36.95 \mathrm{c}$ & - & - & - \\
\hline LSD (P=0.05) & 5.329 & 8.99 & 7.4337 & - & - & - \\
\hline
\end{tabular}

Values within the same column with a common letter do not differ significantly $(\mathrm{P}=0.05)$

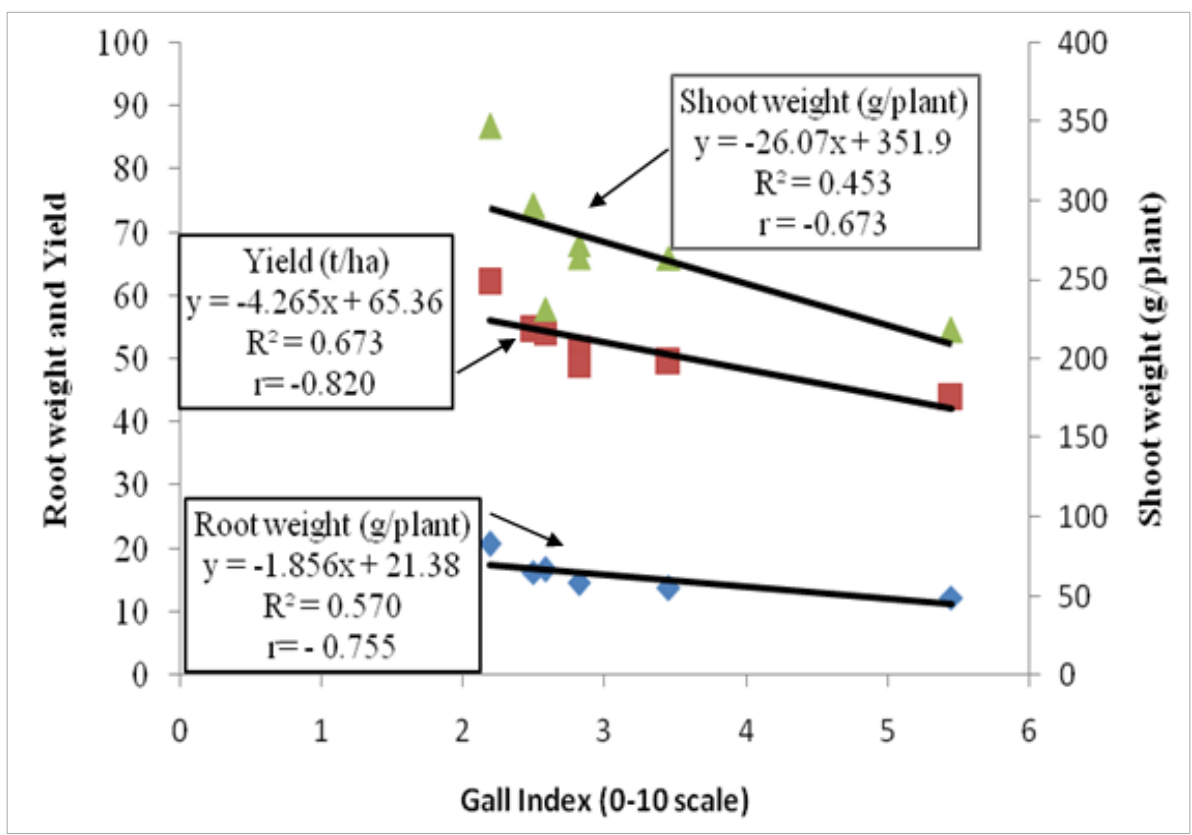

Figure 1. Relationship of shoot weight, root weight and fruit yield with gall index of tomato grown in soil inoculated with Meloidogyne incognita and treated with poultry refuse, rice bran , saw dust, tea waste and Furadan 5G 
In the $2^{\text {nd }}$ year, average fruit yield was 49.73 t/ha under control and 54.56 to $71.62 \mathrm{t} /$ ha under treated plots (Table 4). The highest yield was $71.62 \mathrm{t} / \mathrm{ha}$ obtained from poultry refuse treatment followed by rice bran and Furadan 5G with the yield of 64.40 and $60.04 \mathrm{t} / \mathrm{ha}$, respectively. The highest increase of yield $30.56 \%$ compared to control in poultry refuse treatment which was followed by rice bran Furadan 5G and fresh saw dust where yield was increase $22.77 \%, 17.17 \%$ and $15.81 \%$, respectively over control. The lowest increase $8.85 \%$ than control was achieved with tea waste followed by dry saw dust.

In the $3^{\text {rd }}$ year, average fruit yield was 36.95 t/ha under control treatment and the yield was increase 45.35 to 56.86 t/ha under treated plots (Table 4). The yield increase over control was significant under all treatments with poultry refuse, Furadan 5G and rice bran. The highest yield was obtained with poultry, which was statistically similar to Furadan 5G. Soil amendment with poultry refuse gave the highest increase of yield 35.02 compared to control which was followed by Furadan 5G and rice bran where the yield increase was $28.25 \%$ and $23.39 \%$, respectively over control. The lowest yield increase $18.52 \%$ than control was found under dry saw dust followed by tea waste with $19.64 \%$ higher yield compared to control.

Correlation and regression analysis was performed to find out the relationship of fruit yield, shoot weight and root weight with gall index values of tomato grown in soil inoculated with $M$. incognita and treated with poultry refuse, rice bran , saw dust, tea waste and Furadan 5G (Figure 1). Pooled data on those parameters recorded in three consecutive years were used for this analysis and found that the relationship was linear and negative for fruit yield, shoot weight and root weight with coefficient of correlations (r) $0.820,0.673$ and 0.755 , respectively, The relationship was significant in case of fruit yield, shoot weight and root weight and influence of gall index on those parameters may be attributed to $67.30 \%\left(\mathrm{R}^{2}=0.673\right)$, $45.30 \%\left(\mathrm{R}^{2}=0.453\right)$ and $\left.57.00 \% \mathrm{R}^{2}=0.570\right)$, respectively. The results indicated that organic amendments improved plant growth. It may be due to addition of plant nutrients to the soil. A Lower $\mathrm{R}^{2}$ value indicates that other factors are also involved in plant growth and yield increase.

\section{Discussion}

Plant parasitic nematodes especially root knot nematodes are the major constraint to vegetables production all over the world. Organic amendments have been recognized in the management of plant parasitic nematodes and improvement of soil health. Due to their apparent environmental nontoxic benefits they have been considered in integrated nematode management with inorganic amendments. The present study was designed to determine the potential of organic amendment viz. poultry refuse, rice bran , fresh and dry saw dust and tea waste in the suppression of root-knot nematodes and increasing plant growth as well as yield of tomato in the field. Our results demonstrated that amending field soil with organic amendment viz. poultry refuse, rice bran , fresh and dry saw dust and tea waste suppressed gall index valued caused by root-knot nematode $M$. incognita and increasing plant growth parameters such as shoot length, shoot weight, root length and root weight as well as yield of tomato compared to control. These results are in agreement with that of McSorley and Gallager (31) and Kimpinski et al. (32) who reported that organic amendments from various sources reduce nematode populations. Results of the present study reveal that soil amendment with organic amendments effectively reduced root-knot severity and increased plant growth and fruit yield of tomato grown in $M$. incognita inoculated soil. Chen et al. (33) reported that use of organic amendments in the form of manure and compost effectively decrease parasitic nematode populations and disease intensity on plants. The nematicidal effects of organic amendments may be act directly or indirectly on plant parasitic nematodes. Applications of organic amendments change the soil physical and chemical properties which can improve plant health and making the plants to be more tolerant to nematode and other pathogenic attacks. Nematicidal effects of organic amendments have been attributed to several factors including increase in facultative parasites due to their richness in organic matter and release of toxic substances during decomposition (34, 35). Oka (36) reported that the mechanisms of organic amendments for diseases suppression could be by enhancing the plant resistance through improving the physical, chemical and biological characteristics of the soil. Renco and Kovacik, (23) reported that organic amendments have the ability to not only stimulate beneficial and free living nematodes, but also other important micro flora around the plant rhizosphere that are antagonistic to parasitic nematodes. Decomposing plant residues and other organic amendments release compounds or by products such as nitrogen and organic acids that may have nematicidal effects $(36,37)$. The results of the present study clearly indicated that poultry refuse with bedding materials enhanced plant growth and reduced root knot nematode disease incidence with higher fruits yield of tomato. This result is in agreement with that of Meyer et al. (38) who indicated significant increase in plant height, leaf area, shoot dry weight, stem girth and root dry weight of cacao plants with application of poultry manure. The application of poultry manure has been observed to have a suppressive effect on root-knot nematodes (39). Farahat et al. (40) also reported that efficacy of poultry manure against plant-parasitic nematodes may either be due to stimulation of specific micro-organisms that were capable of parasitizing eggs and juveniles or production of substances from decomposition of the manure which were toxic to the nematodes. From this study it was also 
observed that rice bran significantly enhanced plant growth and reduced root knot nematode incidence as well as increased fruits yield of tomato compared to untreated control. Chun-Yang et al. (41) reported that rice bran has frequently been utilized in the past for soil improvement. Chun-Yang et al. (41) also observed that rice bran ash reduces the plasticity of soils and increased organic matter content. In addition, rice bran was observed to have the ability to reduce plant-parasitic nematode infestation on crops. According to Prakash and Singh (42), nematode density and reproduction decreased progressively with increasing rice bran amendments. Thus it was revealed from the present investigation that soil amendment with poultry refuse was the most effective option for reducing root knot nematode disease and increasing plant growth as well as for higher yield of tomato. The other options were soil treatment with chemical pesticide Furadan 5G or rice bran for reducing root knot disease and increasing plant growth as well as for higher yield of tomato. Similar studies done by Hassan et al. (43) and Orisajo et al. (35) showed that amending the soil with organic waste materials such as poultry refuse, rice bran and saw dust suppressed the populations of Meloidogyne spp. both in the soil and roots of tomato with simultaneous increase in the growth and yield. Oka et al. (35) and Orisajo et al. (44) also reported that application of soil organic amendments is not only beneficial to nematode management but also to plant growth and productivity. Therefore, it may be concluded that soil amendment with poultry refuse is the best treatment followed by soil treatment with chemical pesticide Furadan 5G or rice bran for reducing root knot nematode disease and increasing plant growth as well as yield of tomato.

\section{Acknowledgements}

The authors thankfully acknowledged to Bangladesh Agricultural Research Institute, Gazipur to provide financial support and logistic support for the pieces of research. Thanks go to Mr. Md. Abdur Razzak and Mr. Zamil Akter (Scientific Assistant) for their assistance for successfully complete the research in the field.

\section{REFERENCES}

[1] Food and Agriculture Organization. FAO production years books. Basis Data Unit. Statistics Div. FAO Rome Italy, 1997; 21: 125-127.

[2] Hossain ME, Alam MJ, Hakim MA, Amanullah ASM, Ahsanulla. An assessment of Physicochemical Properties of Some Tomato Genotypes and Varieties Grown at Rangpur. Bangladesh Res. Pub. J., 2010; 4(3):135-243. Available from http://www.bdresearch publications. com/admin/jour nal/u pload/ 09180/ 09180.pdf
[3] Chowdhury B. Vegetables. 6th Revised Edition, The Director National Book Trust, New Delhi, India. 1979; 45p.

[4] Bangladesh Bureau of Statistics (BBS). Yearbook of Agricultural Statistics of Bangladesh. Bangladesh Bureau of Statistics. Statistics Division, Ministry of Planning, Government of the People's Republic of Bangladesh. 2017: p.301.

[5] Anonymous. FAO production years books. Basic Data Units, Statistics Div. FAO Rome Italy, 1998; 52: 124-125.

[6] Anang BT, Zakaria AZ, Yusif S. Production Constraints and Measures to Enhance the Competitiveness of the Tomato Industry in Wenchi Municipal District ofGhana. American J. of Experimental Agric. 2013; 3(4): 824-838.

[7] Luc M, Sikora RA, Bridge J. Plant-parasitic nematodes in subtropical and tropical agriculture - Second edition. CABI Publishing, Wallingford, UK, 2005a; pp 331-871.

[8] Perry RN, Evans AAF. Survival mechanisms in: Perry, R.N., Moens, M., and Starr, J. L. (eds). Root-knot nematodes. CAB international. London. 2009; 201-220 pp.

[9] Bridge J, Coyne D, Kwoseh CK. Nematodes parasites on root and tuber crops. 2005: Pp. 221-258. In: Plant Parasitic Nematodes in Subtropical and Tropical Agriculture. Second Edition. Luc, M., Sikora, R.A. \& Bridge, J., eds. CAB International. Wallingford, UK.

[10] Sasser JN. Plant Parasitic Nematodes: The Farmer’s Hidden Enemy. North Carolona State University, Raleigh, North Carolona. 1989; 7-14.

[11] Luc M, Hunt DJ, Machon JE. Identification, Morphology and Biology of Plant-parasitic Nematodes In: Luc M., Sikora R.A. and Bridge J. (eds) Plant parasitic nematodes in subtropical and tropical agriculture - Second edition. CABI Publishing, Wallingford, UK 2005b; Pp 11-26.

[12] Mohsin M. Influence of inoculum level on pathogenicity and population development of root knot nematode on potato and susceptibility of its clones to the nematode. M. Sc. (Ag) thesis submitted to the Faculty of Agriculture, Bangladesh Agricultural University, Mymensingh. 1987; 59p.

[13] Anonymous. Annual report (1985-86). Plant Pathology Division, BARI, Joydebpur, Gazipu, 1986: 68p.

[14] Hossain S, Mian IH, Tsuno K. Efficacy of three nematicides and two oilcakes for control of root knot nematode (Meloidogyne incognita) in potato seedlings. J. Fac. Agric. Kyushu University 1989; 34(1\&2): 115-121.

[15] Trivedi PC, Bhannagar A, Tiagi B. Control of nematode on Capsicum annum by application of oil cakes. Indian Phytopathol. 1978; 32(1): 75-76.

[16] Mian IH, Rodrigued-Kabana R. A survey of the nematicidal properties of some organic materials available in Albana as amendments to soil for control of Meloidogyne arenaria, Nematropica 1982; 12(2): 235-246.

[17] Faruk MI, Bari MA, Nahar MS, Rahman MA, Hossain MM. Management of root knot nematode (Meloidogyne) of tomato with two organic amendments and a nematicide. Bangladesh J. Plant Pathol. 2001; 17(1\&2): 27-30.

[18] Bari MA, Faruk MI, Rahman M., Ali MR. Effect of organic soil amendments and nematicide on root-knot nematode of 
brinjal. Bangladesh J. Plant Pathol. 2004; 20 (1\&2): 27-30.

[19] Rao MS, Reddy PP, Nagesh M. Management of root knot nematode, Meloidogyne incognita on tomato by integration of Trichoderma harzianum with neem cake. Zeitschrift-fur-Pflanzenkrankheten-und Pflanzenschutz, 1997; 104(4): 423-425.

[20] Reddy PP, Nagesh M, Devappa V. Management of Meloidogyne incognitaon potato by integration of Trichoderma harzianum, Glomus fasciculatum and neem cake. Advances in IPM for horticultural crops. Proceedings of the First National Symposium on Pest Management in Horticultural Crops: environmental implications and thrust, India. 1998; 349-352.

[21] Siddiqui IA, Haque SE, Gaffar A. Root dip treatment with Pseudomonas aeruginosa and Trichoderma spp. in controlling root knot complex in chilli. Pakistan J. Nematol. 1999; 17: 65-75.

[22] Wachira PM, Kimenju JW, Okoth SA, Mibey RK. Stimulation of Nematode-Destroying Fungi by Organic Amendments Applied in Management of Plant ParasiticNematode. Asian J. of Plant Sci., 2009; 8: 153-159.

[23] Renco M, Kovasik P. Response of Plant Parasitic and Free Living Soil Nematodes to Composted Animal Manure Soil Amendments. J. of Nematology, 2012; 44: 329-336.

[24] D'Addabbo T, Papajova I, Sasanelli N, Radicci V, Renc`o M. Suppression of root-knot nematodes in potting mixes amended with different composted biowastes. Helminthologia 2011; 48: 278-287.

[25] Akhtar M, Malik A. Roles of organic soil amendments and soil organisms in the biological control of plant-parasitic nematodes: A review. Bio resource Technology, 2000; 74: 35-47.

[26] Akhtar M, Mahamood I. Organic Soil Amendment in relation of Nematode management with Particular reference to India. Journal of Integrated Pest Management,2004; 1: 201-205.

[27] Chang EH, Chung RS, Tsai YH. Effect of different application rates of organic fertilizer on soil enzyme activity and microbial population. Soil Science and Plant Nutrition, 2007; 53: 132-140.

[28] Bailey KL, Lazarovits G. Suppressing soilborne diseases with residue management and organic amendments. Soil and Tillage Research, 2003; 72: 169-180.

[29] Anonymous. Research Report on Horticultural Crops (2006-07). Horticulture Research Centre, BARI, Joydebpur, Gazipu, 2007: 91p.

[30] Zeck MW. A rating scheme for field evaluation of root knot nematode infestation. Planzenschuta-Nacht, 1971; 24: 141-144.

[31] McSorley R, Gallaher RN. Effect of yard waste compost on plant-parasitic nematode densities in vegetable crops. J. Nematol. 1995; 27: 545-549.

[32] Kimpinski J, Gallant CE, Henry R, Macleod JA, Sanderson JB, Sturz AV. Effect of compost and manure soil amendments on nematode and on yields of potato and barley: a 7-years study. Nematology, 2003; 35: 289-293.
[33] Chen J, Abawi GS, Zuckerman BM. Efficacy of Bacillus thuringiensis, Paecilomyces marquandii and Streptomyces constaricanus with and without organic amendment against Meloidogyne hapla infecting lettuce. J. of Nematol., 2000; 32: 70-77.

[34] Oka Y, Yermiyahu U. Suppressive effects of composts against the root-knot nematode Meloidogyne javanica on tomato. Nematology. 2002; 4: 891-898.

[35] Oka Y, Tkachi N, Shuker S, Yermiyahu U. Enhanced nematicidal activity of organic and inorganic ammonia-releasing amendments by Azadirachta indica extracts. Journal of Nematiology 2007; 39: 9-16.

[36] Oka Y. Mechanisms of nematode suppression by organic soil amendments - A review. Applied Soil Ecology 2010; 44: 101-115.

[37] Thoden TC, Korthals GW, Termorshuizen AJ. Organic amendments and their influences on plant-parasitic and free-living nematodes: a promising method for nematode management. Nematology, 2011; 13: 133-153.

[38] Meyer SLF, Orisajo SB, Chitwood DJ, Vinyard BT, Millner PD. Poultry litter, compost for suppression of root-knot nematode on cacao plants. International Journal of Nematology 2011; 21 (2): 153-162.

[39] Orisajo SB, Okeniyi MO, Fademi OA, Dongo LN Nematicidal effects of water leaf extracts of Acalypha ciliata, Jatropha gossypi folia, Azadirachta indica and Allium ascalonicum on Meloidogyne incognita infection on cacao seedlings. J. of Res. in Bioscience 2007; 3 (3): 49-53.

[40] Farahat AA, Al-Sayed AA, Mahfoud NA. Compost and other organic and inorganic fertilizers in the scope of the root-knot nematode reproduction and control of Meloidogyne incognita infecting tomato. Egyptian. Journal of Agronematology. 2010; 9: 18-29.

[41] Chun-Yang Y, Mahmud HB, Shaaban MG. Stabilization/solidification of lead-contaminated soil using cement and rice bran ash. Journal of Hazardous Materials, 2006; 137(3): 1758-1764.

[42] Hassan MA, Chindo PS, Marley PS, Alegbejo MD. Management of Root Knot Nematodes (Meloidogyne spp.) on Tomato (Lycopersicon lycopersicum) Using Organic Wastes in Zaria, Nigeria. Plant Protection Sciences. 2010; 46 (1): 34-38.

[43] Orisajo SB, Afolami SO, Fademi O, Atungwu JJ. Effects of poultry litter and carbofuran soil amendments on Meloidogyne incognita attacks on cacao. Journal of Applied Biosciences, 2008; 7: $214-221$.

[44] Prakash J, Singh K. Impact of rice bran on population density and reproduction of tomato parasitised root-knot nematodes. European J. of Biotech. and Biosci. SSN: 2014; 2321-9122. Available at www.biosciencejournals.com(acc essed 2nd March 2015). 